\title{
Study on Environment Effect of Construction in Huairou District Xing Kuang ${ }^{1, a}$
}
${ }^{1}$ Northern Beijing Vocational Education Institute Department of architectural engineering, Beijing 101400

a05115207@bjtu.edu.cn

\begin{abstract}
Keywords: Huairou district; Ecological sensitive area; Construction; Environmental impact.
\end{abstract}
\begin{abstract}
Huairou city is an important node in the northern Beijing City Development Zone, is an important base for the capital, conference, leisure tourism, a construction project in the "ecological conservation development areas" of Huairou, human construction, construction period prone to Forestland grassland destruction, to produce a rock mass damage, destruction of soil, the occurrence of soil and water loss, water pollution noise impact, the atmosphere and water environment, and have a certain impact on the city of biomass and landscape, is studied and the conclusion is given in this paper, the main aspects of the influence of Huairou District Engineering Construction on the environment.
\end{abstract}

\section{Introduction}

Huairou is an important node in northern Beijing. And it is not only an important water source protection and ecological barrier of Beijing, but also an important part of the surrounding green network system. Huairou District, located in the northern part of Beijing, has good natural environment and favorable conditions for the development of an international convention, and is an important area to play international exchanges function.

The Natural Environment. 88.7\% of Huairou District is the total area of the mountainous region. There were the mountains, hills, plains from north to south. Famous peaks are nearly 500, the land area is nearly 213,000 hectares, 18,000 hectares of arable land, 148,000 hectares of forest land. Annual rainfall of $600 \sim 700 \mathrm{~mm}$, mainly in June to August[1]. Huairou District, where major projects are mainly Quaternary Holocene Piedmont alluvial material, lithology is mainly gravel layer, the maximum thickness of more than $80 \mathrm{~m}$, its surface distribution of clayey silt $3.0 \sim 5.0 \mathrm{~m}$ and sand layers.

Soil Environment. The engineering soils of mountainous area are many classes soil slopes, including residual soil slope, all weathered and highly weathered soft rock slope and so on. Class of soil slope with a weak structural plane similar to the rock.

According to the material class cutting slope soil composition, genetic mechanism and structural characteristics of slope, there are residual soil slope slope, weathered soil slope, slump flow deposits slope, see Figure 1.
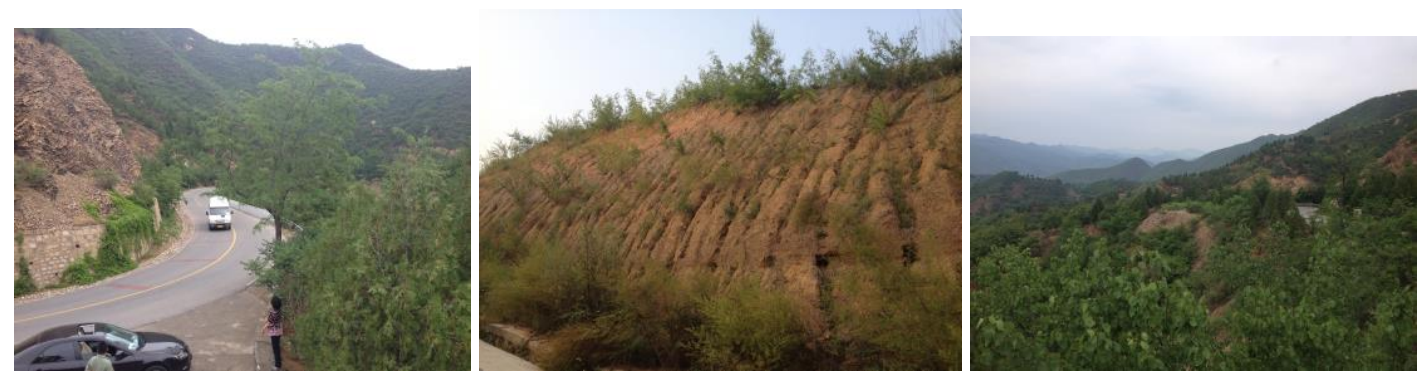

Figure. 1 residual soil slope map, weathered slope, slump-flow deposits Slope 


\section{Engineering Construction and Environmental Protection Measures}

Environmental Impact Surveys.Singapore residual soil slope in highway engineering, under the action of rainfall and excavation cutting in the toe of slope, easy to produce slope sediments overlying rock layers slump and failure occur. Weathered soil slope, a common weakness with some strongly weathered, if its occurrence tends to slope, easy to produce large-scale deformation slide and destruction. Slump flow deposits in the slope, prohibit construction ${ }^{[2]}$. Where residual soil slope and soil slope under the influence of weathering, soil erosion phenomenon is evident in Figure 1.

In existing infrastructure in River system, it is investigated and found that most of the aging water system building, are seriously damaged, can not meet the needs of urban functions limited functionality, water circulation loop, self-purification and so on. It is shown in Figure 2.
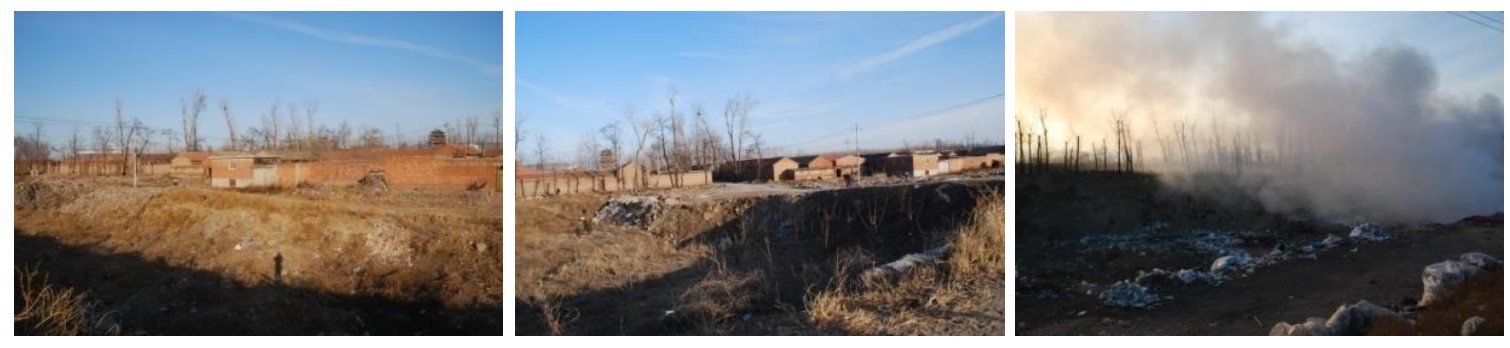

Figure. 2 serious environmental pollution in Riverfront area

Environmental Protection Measures in Building Construction. The environmental protection organization, atmospheric and environmental protection measures, noise, water, environment, environmental and safety field data were investigated in Ya-Yuan Project of the Golden Bridge Construction Group ${ }^{[3]}$.

The green construction for Yan-xi Lake International Project Department of Beijing Urban Construction Group will have conducted an investigation activities ${ }^{[4]}$. The project is to meet excellent requirements of the "green building construction project evaluation criteria" ${ }^{\text {[5] }}$ (GB/T50640-2010) and to ensure that reached the three-star standards of the national "Green Building Evaluation Standard" ${ }^{16]}$ (GB / T 50378-2006), and "Green Building Evaluation Standard"

Green Protective Measures. 2013 forest management tending area of Huairou district is 84,000 acres, and the total investment is $25,896,600$ yuan. Where the forest management demonstration area project area is 3888 acres. 2014 APEC meeting held in Huairou, near Yan-xi lake. About 900 million yuan is invested starting in 2012. Three key greening projects are implemented, and an ecological District is created.

\section{Environmental Impact Factors of Sensitive Areas During Construction}

Atmospheric Environment. Impact factors of construction on the atmospheric environment is mainly road construction, earth moving, construction waste and other dust-based. Controls carried out during the construction. Whether the heating method is considered during the use of major construction projects. So the contents of the atmosphere can be only general analyzed.

Sound Environment. Noise pollution in construction process is mainly of machinery noise and vehicle traffic noise. Be course most of the current situation of Huairou district is rural areas, the environmental quality of the national noise is in "Class 1 standard."of "sound environmental quality standards" (GB3096-2008) other main road for example 101 State Road, Huai Yang Road, Huai Geng Road, Huaichang connections, Chang Huai Road, river patrol secondary roads, is implemented in " class 4a standards "of the national "acoustic environmental quality standards" ${ }^{[8]}$ (GB3096-2008), which can be see in Table 1. After the completion of the project construction, noise of operation period is smaller which will not be considered.

Table 1 acoustic environmental quality standards (dB (A))

\begin{tabular}{|c|c|c|c|}
\hline \multirow{2}{*}{ class } & \multirow{2}{*}{ standards } & \multicolumn{2}{|c|}{ noise limits } \\
\cline { 3 - 4 } & & Day & night \\
\hline class of District 1 & Class 1 standards & 55 & 45 \\
\hline Traffic on both sides of Route & Class 4a standards & 70 & 55 \\
\hline
\end{tabular}


Implementation of the relevant provisions in the construction project is "Construction Site Noise Limits" (GB12532-90) ${ }^{[9]}$ in the construction phase, detailed in Table 2.

Table 2 noise limits for construction site $(\mathrm{dB}(\mathrm{A}))$

\begin{tabular}{|l|l|l|l||}
\hline Construction Phase & Class & day & night \\
\hline Earthwork & bulldozers, excavators, loaders and other & 75 & 55 \\
\hline Piling & various hammers and other & 85 & prohibit construction \\
\hline Structural & $\begin{array}{l}\text { concrete mixer vibrator, electric saws } \\
\text { and other }\end{array}$ & 70 & 55 \\
\hline Decoration & cranes, lifts & 60 & 55 \\
\hline
\end{tabular}

\section{The Impact of Construction Projects on Soil Erosion}

Soil Erosion Modulus Disturbed Ago. According to the status of remote sensing results of soil erosion in Beijing, mainly of soil erosion is water erosion and is mainly in mountainous and hilly areas. Based on "Water Conservation Bulletin Beijing" ${ }^{[10]}$ and other information, the location of the project area is mild water erosion of soil erosion and soil erosion modulus is about $500 \mathrm{t} / \mathrm{Km}^{2} \cdot \mathrm{a}$.

Soil Erosion Modulus After Disturbance. The main period of soil erosion is during construction phase of the project, especially during the subgrade excavation and backfill construction activities. Determining soil erosion modulus of engineering after disturbance, using the analogy analysis and field survey methods Combination, the project area is moderately eroded soil erosion. Soil erosion modulus of the project is $1000 \mathrm{t} / \mathrm{km}^{2} \cdot \mathrm{a}$. Main project area is a major source of soil erosion. Therefore, we must develop practical water conservation measures and effective erosion control.

\section{Conclusions and Recommendations}

The environment impact during the construction in sensitive areas of Huairou District is mainly on soil erosion and ecological environment. Soil erosion reduction and governance issues can be through water conservation measures, as long as careful implementation of water conservation measures. Influence of green biomass of urban ecological landscape is the next need for green landscape engineering and other rational planning and construction.

\section{Acknowledgements}

Relying on Beijing Huairou District talents training aid issues."study on the environmental impact in ecological sensitive areas of the construction of Huairou District ", Beijing Higher Education Reform Projects of " Civil Engineering Vocational Curriculum Reform of skill building and professional contest convergence " and university project of Northern Beijing Vocational Education Institute Department of architectural engineering

\section{References}

[1] Beijing Municipal People's Government. Beijing City Master Plan (2004-2020). p.10-11

[2] X.P. Zhang. Analysis and applied Research on Class soil slope failure mechanism.(Ph.D., Beijing University of Science and Technology, China 2007), p.33

[3] Beijing Urban Construction Group Co., Ltd. .China Architecture Design and Research Innovation Center research and demonstration program of green construction special construction. 2013.p.6-9

[4] China Architecture Design \& Research innovation research and demonstration center.Green Construction Special Construction Project.2013.p.23-27 
[5]The national standard of the people's Republic of china:Building Green Construction Project Evaluation Criteria.GB / T50640-2010.China Planning Press.p.74

[6]The national standard of the people's Republic of china:Green Building Evaluation Standard.GB / T 50378-2006.p.39

[7] People's Republic of China Ministry of Environmental Protection. Green Building Evaluation Standard.DB11 / T825- 2011.p.82

[8] People's Republic of China Ministry of Environmental Protection. Acoustic Environmental Quality Standard.GB3096-2008. 2008.p.43

[9] People's Republic of China Ministry of Environmental Protection. Noise limits for construction siteGB12523-2011. p.54

[10] Beijing Water Conservation Station.Water Conservation communique in Beijing.2012.p.35 